International Journal of Agriculture, Environment and Bioresearch

Vol. 5, No. 06; 2020

ISSN: $2456-8643$

\title{
INFLUENCE OF REPEATED CROPS AND DIFFERENTIATED APPLICATION OF THE RATES OF MINERAL FERTILIZERS ON THE FERTILITY OF ERODED TYPICAL GRAY SOILS AND THE YIELD OF WINTER WHEAT
}

\author{
Bobur Mansurovich Kholmurzaev ${ }^{1}$ and Zulfiya Komilova Muminova ${ }^{2}$ \\ ${ }^{1}$ Basic Doctoral Student (PhD), Department of Agrotechnology, Samarkand Institute of Veterinary Medicine, \\ Samarkand, Uzbekistan \\ ${ }^{2}$ Candidate of Biological Sciences, Senior Lecturer of the Department Agrotechnology, Samarkand Institute of \\ Veterinary Medicine, Mirzo Ulugbek street, 77, Samarkand, Uzbekistan \\ https://doi.org/10.35410/IJAEB.2020.5581
}

\begin{abstract}
Based on the results of the study, criteria for the selective introduction of suitable secondary crops (beans, mung bean, soybeans) and perennial alfalfa and mineral fertilizers were selected, which reduce the negative effects of irrigation erosion, increase soil fertility, and ensure the production of high-quality grain from winter wheat. The results show that, after repeated crops, the volume mass of the $0-30 \mathrm{~cm}$ layer of soil is $0.03-0.05 \mathrm{~g} / \mathrm{cm} 3$ less than in the case of unwashed soils compared to the initial value, the porosity is $1.9-2.5 \%$ higher, in heavily washed soils respectively $0.02-0.04 \mathrm{~g} / \mathrm{cm} 3$ less and 1.7-2.3\% higher, compared to the control of soil water permeability 38.3-51.2 $\mathrm{m} 3 /$ ha and at the end of the period of application 24.9-42.7 $\mathrm{m} 3$ Grain yield in unwashed varieties under the influence of repeated crops and mineral fertilizers (N150P105K75 kg / ha), providing favorable conditions for full germination, growth and development of winter wheat seeds (92.3-91.5\%), providing grain yield in unwashed soil variants (68.8-72.4 c/ha), protein content from 14.8-15.6 and gluten 31.8-32.4\%, mineral fertilizers (N180P126K90 kg/ha) after repeated sowing of the above in areas with strongly washed soils in the applied variants are 69.2-74.5 c/ha, 15.2-15.8 and 32.1-32.8\%, respectively, plays an important role in ensuring food security of the population during the current coronavirus pandemic.
\end{abstract}

Keywords: Typical Serozem, Irrigation Erosion, Fertility, Winter Wheat, Grain Yield, Quality, Repeated Crop.

\section{INTRODUCTION}

The use of agricultural technologies for the cultivation of secondary, intermediate and green manure crops to prevent and control the degradation of the irrigated soil cover in the Republic of Uzbekistan is the basis for improving the water-physical, agrochemical and microbiological properties and biological activity of the soil [1]. 
In Uzbekistan alone, irrigated arable land is 685.7 thousand hectares, including 121.9 thousand hectares in Samarkand region [2]. Under the influence of irrigation erosion, humus in typical gray soils and some of the nutrients necessary for the growth and development of major agricultural crops: nitrogen, phosphorus, potassium, etc. are washed away by irrigation water and leave the crop fields. As a result, soil fertility, yields of cotton, winter wheat, corn and other crops are reduced by an average of 30-40\%, and residues of mineral fertilizers and pesticides in the soil fall into water sources, adversely affecting the environment $[3,4]$.

In order to ensure food security of the population in Uzbekistan, special attention should be paid to maintaining and increasing the fertility of typical gray soils subject to irrigation erosion in order to grow high-quality grain from winter wheat. In the conditions of irrigated agriculture of the Republic, which has the ability to grow 2-3 times a year, one of the most important issues in increasing the productivity of irrigated eroded soils, the selection of optimal secondary and past crops, the development of agro-technologies for their cultivation.

Traditional farms and cluster farms in the country, based on their economic and social interests and goals, use the following crops: legumes (mung bean, soybeans, beans, china, lentil), grain (corn, white corn, sugar corn), oilseeds (flax, sesame, sunflower, maskhar) can be planted selectively. However, given the current market economy and declining soil fertility, it is advisable to grow more legumes as a secondary crop in irrigated eroded gray soils. This is due to the fact that they serve, firstly, to increase the fertility of gray soils that have lost their fertility due to erosion, and secondly, to provide the population with valuable, protein-rich foods and adequate feed for livestock. Today, based on the experience of a number of countries around the world (USA, Brazil, India, China, etc.), the task of solving the main problems of crop rotation in farms, clusters and private farms is assigned to legumes $[4,5,6,7,8]$. When these crops are grown as secondary crops, twice the grain yield is obtained in one field, most importantly, conditions are created to maintain and increase the fertility of typical gray soils subject to irrigation erosion, creating a favorable and environmentally friendly environment for plants in the soil [9].

Harvesting at least twice a year from agricultural crops grown under typical eroded gray soils, to meet the population's demand for food, to maintain and increase soil fertility, to grow legumes as a nitrogen-fixing crop in the soil. One of the most pressing issues is the scientific substantiation of the impact of the selection of effective varieties, their cultivation and differentiated application of mineral fertilizers on the yield and quality of winter wheat.

Research objectives: Determination of the impact on the cultivation of rich, high-quality grain from winter wheat and soil fertility by determining the optimal standards for the selection, cultivation and application of mineral fertilizers stratified by erosion, ensuring the maintenance and increase of fertility of typical gray soils of Samarkand region.

Research tasks: to study the technology of growing leguminous crops in the conditions of typical gray soils affected by irrigation erosion and to distinguish them from the most suitable type for these conditions; to determine the amount of nutrients and root residues in them, the amount of NPK and nutrients returned to the soil in areas where the soil of the field is not 
washed and strongly washed; to determine the impact of repeated legume-grain crops on the agrophysical, agrochemical and microbiological properties of eroded soils, winter wheat yield and technological quality of grain, and to assess the economic efficiency of winter wheat cultivation.

\section{MATERIALS AND METHODS}

In order to carry out the above tasks, the objects of our research are: typical gray soils prone to irrigation erosion, different rates of mineral fertilizers and the method of using them by differentiation, "Grom" variety of winter wheat, "Tashkent" as a secondary crop, "Ravot, Productive" as beans, pea "Vostok-55", soybean" Orzu", alfalfa "Dimitra" varieties were grown.

Field experiments in 2016-2019 in the typical structure of irrigated eroded gray soils of the farm "Mansurov Muzaffar fayzli zamini" in Jambay district of Samarkand region in the following structure: 1. Autumn wheat - plow (control) + autumn wheat, 2. Beans + autumn wheat; 3. Mung bean + autumn wheat; 4 . Soy + autumn wheat; 5 . Pea + autumn wheat; 6 . Alfalfa + autumn wheat was planted. The studies were conducted in 4 repetitions, with a total area of $901.6 \mathrm{~m}^{2}$ (length of field $161 \mathrm{~m}$, of which $61 \mathrm{~m}$ of soil was unwashed, $72 \mathrm{~m}$ of heavily washed and $28 \mathrm{~m}$ of washed soil, width 8 rows $\times 0.7 \mathrm{~m}=5.6 \mathrm{~m} \times 161=901.6 \mathrm{~m}^{2}$ ), of which $450.8 \mathrm{~m}^{2}$ were taken into account, the options were placed schematically in one tier.

Table 1 .Scheme of the experiment

\begin{tabular}{|c|c|c|c|c|c|c|c|c|c|}
\hline \multirow{3}{*}{$\begin{array}{l}\mathbf{N} \\
\mathbf{o}\end{array}$} & \multirow{3}{*}{$\begin{array}{l}\text { Options of the } \\
\text { experiment }\end{array}$} & \multirow{2}{*}{\multicolumn{3}{|c|}{$\begin{array}{l}\text { Annual norm of } \\
\text { nutrient } \quad \text { elements } \\
(\mathrm{NPK}), \mathrm{kg} / \mathrm{ha}\end{array}$}} & \multirow{2}{*}{\multicolumn{2}{|c|}{$\begin{array}{l}\text { Under } \\
\text { plowing, } \\
\text { kg/ha }\end{array}$}} & \multirow{3}{*}{$\begin{array}{l}\text { With } \\
\text { plantin } \\
\text { g, } \\
\text { kg/ha } \\
\mathrm{P}_{2} \mathrm{O}_{5}\end{array}$} & \multicolumn{2}{|c|}{ Autumn wheat } \\
\hline & & & & & & & & \multirow{2}{*}{$\begin{array}{l}\text { Period of } \\
\text { colletcting }\end{array}$} & \multirow{2}{*}{$\begin{array}{l}\begin{array}{l}\text { Period of } \\
\text { stucking }\end{array} \\
N\end{array}$} \\
\hline & & $N$ & $\boldsymbol{P}_{2} \boldsymbol{O}_{5}$ & $\boldsymbol{K}_{2} \boldsymbol{O}$ & $\mathrm{P}_{2} \mathrm{O}_{5}$ & $\boldsymbol{K}_{2} \mathrm{O}$ & & & \\
\hline \multirow[t]{2}{*}{1} & \multirow{2}{*}{ 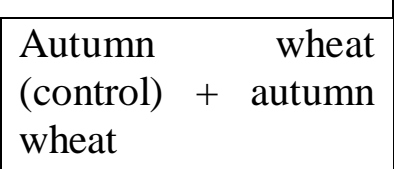 } & - & - & - & - & - & - & - & - \\
\hline & & - & - & - & - & - & - & - & - \\
\hline \multirow[t]{2}{*}{2} & \multirow{2}{*}{$\begin{array}{lr}\text { Autumn } & \text { wheat }+ \\
\text { autumn } & \text { wheat } \\
\text { (control) } & \end{array}$} & 180 & 126 & 90 & 101 & 90 & 25 & 90 & 90 \\
\hline & & 150 & 105 & 75 & 80 & 75 & 25 & 75 & 75 \\
\hline \multirow[t]{2}{*}{3} & \multirow{2}{*}{$\begin{array}{l}\text { Beans }+ \text { autumn } \\
\text { wheat }\end{array}$} & 180 & 126 & 90 & 101 & 90 & 25 & 90 & 90 \\
\hline & & 150 & 105 & 75 & 80 & 75 & 25 & 75 & 75 \\
\hline \multirow[t]{2}{*}{4} & \multirow{2}{*}{$\begin{array}{l}\text { Mung bean }+ \\
\text { autumn wheat }\end{array}$} & 180 & 126 & 90 & 101 & 90 & 25 & 90 & 90 \\
\hline & & 150 & 105 & 75 & 80 & 75 & 25 & 75 & 75 \\
\hline
\end{tabular}


International Journal of Agriculture, Environment and Bioresearch

Vol. 5, No. 06; 2020

ISSN: $2456-8643$

\begin{tabular}{|l|l|l|l|l|l|l|l|l|l|}
\hline 5 & Soy + autumn wheat & 180 & 126 & 90 & 101 & 90 & 25 & 90 & 90 \\
\cline { 3 - 10 } & 150 & 105 & 75 & 80 & 75 & 25 & 75 & 75 \\
\hline 6 & \multirow{2}{*}{\begin{tabular}{l} 
Pea + autumn wheat \\
\cline { 3 - 10 }
\end{tabular}} & 180 & 126 & 90 & 101 & 90 & 25 & 90 & 90 \\
\cline { 3 - 10 } & $\begin{array}{l}\text { Alfalfa (1 year) + } \\
\text { autumn wheat }\end{array}$ & 90 & 120 & 90 & 101 & 95 & 25 & 45 & 45 \\
\hline
\end{tabular}

In the experimental field, the groundwater is located at a depth of 14-16 meters, so these soils are not salted with harmful salts. Medium and light sand on the mechanical composition of the soil, the slope of the field under study is 0.005 meters. The amount of humus in the plowed $(0-30 \mathrm{~cm})$ layer of strongly washed and unwashed parts of the experimental field soils was $0.885-1.152 \%$, total nitrogen $0.73-0.117$, phosphorus $0.112-0.194$, potassium $1.975-2.216 \%$, respectively, the amount of their mobile forms: nitrate nitrogen $\left(\mathrm{N}-\mathrm{NO}_{3}\right)-11.54-16.11$, mobile phosphorus $\left(\mathrm{P}_{2} \mathrm{O}_{5}\right)$ 12.66-15.83 and exchangeable potassium $\left(\mathrm{K}_{2} \mathrm{O}\right)-230-270 \mathrm{mg} / \mathrm{kg}$ in soil respectively.

The agrophysical and agrochemical properties of the studied field soils were analyzed in the following ways:

- Mechanical composition of typical gray soils subject to irrigation erosion is analyzed by way of pipette, the amount of water-resistant aggregates in the soil according to N.A.Kachinsky, volume mass by the way of cylindrical method -4 repetitions, comparison mass by pycnometer method 4 repetitions, soil porosity by calculation, soil water permeability $\left(\mathrm{m}^{3} / \mathrm{ha}\right)$ were analyzed by N.A.Kachinsky method [10] in 10 repetitions in unwashed and strongly washed parts of the field soil.

- Humus in the soil by the method of I.V.Tyurin GOST-26213; nitrate nitrogen - by ion-selective method, GOST-13496-10; total nitrogen, phosphorus, potassium were determined in one sample by I.M.Maltseva, L.P.Gritsenko method, mobile phosphorus by B.P.Machigin and exchangeable potassium P.V.Protasov methods, carbonates by Knop method [10].

Norms of nitrogen 60-180, phosphorus $90-126$ and potassium $60-90 \mathrm{~kg} / \mathrm{ha}$ were used in the feeding of autumn wheat in the experimental field. At the same time, $80 \%$ of the annual rate of phosphorus fertilizers was applied under plowing, the remaining $20 \%$ at the same time as sowing seeds, all annual rates of potassium were given under plowing, and annual rates of nitrogen fertilizers were given at the recommended intervals for crops studied during plant growth.

Ammonia nitrate $\left(\mathrm{NH}_{4} \mathrm{NO}_{3}-\mathrm{N}-34,5\right)$, ammophos $\left(\mathrm{NH}_{4} \mathrm{H}_{2} \mathrm{PO}_{4}-\mathrm{N}-10 \%, \mathrm{P}_{2} \mathrm{O}_{5}-46 \%\right)$, potassium chloride $\left(\mathrm{Kl}-\mathrm{K}_{2} \mathrm{O}-58-60 \%\right)$ were used in the experimental field from nitrogen fertilizers. 
All phenological observations and biometric measurements carried out at the experimental site were performed on replanted crops (beans, mung bean, soybeans, pea pods) and on autumn wheat modules $\left(0.5-1.0 \mathrm{~m}^{2}\right)$ marked in each variant and repetition. In this case, the germination rate of autumn wheat seeds, \%; in developmental periods (accumulation, tubing, germination, flowering, milk-wax and full ripening) 25-75\%; number of autumn wheat bushes; before winter, in early spring, at the end of the validity period (in pieces per $1 \mathrm{~m}^{2}$ ); Distribution and mass of plant root system by soil layers, number of spikelets per $1 \mathrm{~m}^{2}$, spike length and number of grains in it, mass of 1000 grains per spike, grain per $1 \mathrm{~m}^{2}$ of grain, vitreousness and nature of grain TU Uz-8-115-9,7 according to GOST - 13586, 5-93, the protein content of the grain was determined by the Barnstein method, the yield - moisture content of the grain was adjusted to the standard (14\%) [11]. Statistical analysis of the data was performed using B.A.Dospekhov's method [12] using Microsoft Excel program.

\section{RESULTS AND DISCUSSION}

The results of our research have shown that repeated crops planted after their predecessors (autumn wheat) have improved soil agrophysical, water-physical and reclamation conditions and maintained soil fertility, leaving ditches and root remnants in the soil. The volume mass of the top seedbed (0-30 cm) of typical gray soils subject to irrigation erosion is $1.33-1.34 \mathrm{~g} / \mathrm{cm}^{3}$ in the unwashed part of the field soil, porosity $50.8-51.6 \%$, and 1.35 in the heavily washed part of the soil. $-1.37 \mathrm{~g} / \mathrm{cm}^{3}$ and $48.7-49.5 \%$, taking into account the fact that these figures varied under the influence of repeated crops at the beginning of the period of application of autumn soft wheat. For example, the volume mass of the soil of the control (plowed) variant of the unplanted crop increased by $0.02-0.03 \mathrm{~g} / \mathrm{cm}^{3}$ compared to the initial value in the unwashed part of the soil of the experimental area, while the porosity decreased by $1.8-2.3 \%$, it was noted that these values were $0.03-0.05 \mathrm{~g} / \mathrm{cm}^{3}$ more and $2.1-3.4 \%$ less, respectively, in areas where the soil was heavily washed.

Volume mass of the plowed $(0-30 \mathrm{~cm})$ layer of soil after repeated crops (beans, mung bean, soybeans, peas, alfalfa) grown under typical gray soils subject to irrigation erosion, $0.03-0.05$ $\mathrm{g} / \mathrm{cm}^{3}$ in the unwashed part of the soil of the experimental area and increased porosity by 1.9$2.5 \%$, while these values were found to be less than $0.02-0.04 \mathrm{~g} / \mathrm{cm}^{3}$ and $1.7-2.3 \%$ higher, respectively, in strongly washed soils.

It was observed that the repeated crops grown in the strongly washed part of the soil of the experimental area had a significant effect, first of all, on the volume mass of the soil. The results of the study showed that, regardless of the type of repeated crops, as the soil fell into the bottom layers, its volume increased and its porosity decreased to $1.36-1.39$, after sowing and 1.37-1.41 $\mathrm{g} / \mathrm{cm}^{3}$ at the end of the autumn wheat period, and the porosity of the soils in this layer is 47.648.5; 49.3 - 50.2 and 48.6 - 49.5\% respectively. These data show that repeated crops (beans, mung bean, soybeans, peas, alfalfa) reduce the bulk mass of soils by $0.03-0.05 \mathrm{~g} / \mathrm{cm}^{3}$, increase the porosity by $2.3-2.8 \%$, followed by the growth of sown autumn wheat and it was found that the most favorable conditions for its development were created. 
The results obtained in the process of determining the effect of repeated crops on soil water permeability in the cultivation of autumn wheat in the conditions of typical gray soils subject to irrigation erosion show that this property of the soil is inextricably linked with its washing rate, density and porosity. For example, in the uncontrolled part of the experimental field, in the control (plowing) variant of repeated sowing, $138.5 \mathrm{~m}^{3} / \mathrm{ha}$ in the 1 st hour before sowing of autumn wheat seeds or $362.3 \mathrm{~m}^{3} / \mathrm{ha}$ in the total 3 hours, $4-5-6215.2 \mathrm{~m}^{3} / \mathrm{ha}$ or $577.5 \mathrm{~m}^{3} / \mathrm{ha}$ in 6 hours, at the end of the autumn wheat period it was formed 105.8 or $304.4 \mathrm{~m}^{3} / \mathrm{ha}, 167.5$ or 471.9 $\mathrm{m}^{3} /$ ha, respectively.

In our study, in order to increase the fertility of typical gray soils subject to irrigation erosion and to protect them from washing, the water permeability of soils in the varieties grown by repeated crops (beans, mung bean, soybeans, peas, alfalfa) in the 1st hour before sowing of autumn wheat seeds $138.6-151,2$ or $356.3-388.5 \mathrm{~m}^{3} / \mathrm{ha}$ in 3 hours in total, $209.5-230.2 \mathrm{~m}^{3} / \mathrm{ha}$ in $4-5-6$ hours of observations, or $585.8-618.7 \mathrm{~m}^{3} / \mathrm{ha}$ in 6 hours in total. At the end of the period, these indicators were $109.2-118.5$ or $275.6-290.3$ and $160.4-182.7$ or $486.8-521.6 \mathrm{~m}^{3} /$ ha respectively. The data show that the high water permeability of soils in the unwashed and heavily washed areas of the experimental area was observed in all variants, depending on the type of repeated crop, in the first 3 hours of the experiment, and then the water permeability of soils in both parts was equalized in 5-6 hours. Thus, repeated crops grown under typical gray soil conditions under irrigation have a positive effect on soil water permeability, with 38.3-51.2 and less at the end of the control period than in the control (repeated sowing, plowing) period before sowing of autumn wheat seeds in heavily washed soils. It was taken into account that $24.9-42.7 \mathrm{~m}^{3} / \mathrm{ha}$ provided more water absorption than normal.

After harvesting of replanted crops (beans, mung bean, soybeans, peas, alfalfa) grown to increase the fertility and autumn wheat yields of typical gray soils subject to irrigation erosion, the amount of mobile nitrogen, phosphorus and exchangeable potassium in the soil in the unwashed and heavily washed areas positively affecting the initial index $\left(\mathrm{N}-\mathrm{NO}_{3}-16,14-11,54 ; \mathrm{P}_{2} \mathrm{O}_{5}-\right.$ $\left.15,83-12,66 ; K_{2} O-270-230 \mathrm{mg} / \mathrm{kg}\right)$ in the top seedbed $(0-30 \mathrm{~cm}) 4.5-3.8$ according to the above shown; $3.2-2.7$ and $26-20 \mathrm{mg} / \mathrm{kg}$ were found to be abundant in the soil, creating the most favorable conditions for full germination, growth and development of autumn wheat seeds and cultivation of high and quality grain crops.

In our experiments, it was observed that repeated crops had a significant effect on the germination of autumn wheat seeds. For example, the soil of the not replanted area was not washed - the germination of autumn wheat seeds in the control plots averaged 82.5-83.7\%, while these figures were found to be $79.3-80.5 \%$ in the heavily washed part of the field. The germination rate of autumn wheat seeds sown after repeated crops (beans, mung bean, soybeans, peas, alfalfa) studied under these conditions was 90.6-92.3 and 89.8-91.5\%, respectively, in the unwashed and strongly washed parts of the field soil. When sowing autumn wheat in the first year after sowing, the germination of its seeds is $1.8-2.6 \%$ in the unwashed part of the field and that was taken into account that it was grown $1.3-1.9 \%$ more in the heavily washed part of the field compared to the germination of seeds sown after beans, mung bean and soybeans. This was found to have an effective effect on the growth and development of autumn wheat by providing a 
Vol. 5, No. 06; 2020

ISSN: $2456-8643$

flat 92.3 and $91.5 \%$ yield in all parts of the field (soil unwashed and vigorously washed) of autumn wheat seeds sown after repeated crops.

According to the results of the study, the total number of stalks in the experimental field soil unwashed-control (autumn wheat, plow) was 504.5 units $/ \mathrm{m}^{2}$, productive stems 365.3 units $/ \mathrm{m}^{2}$, which is 493.2 in the heavily washed part of the field, and 351.6 units $/ \mathrm{m}^{2}$. The total number of stems in areas where the soil is not washed away by repeated crops (beans, mung bean, soybeans, peas, alfalfa) is $515.4-567.8$ units $/ \mathrm{m}^{2}$ or $10.9-63.3$ units $/ \mathrm{m}^{2}$ compared to the control, and the number of productive stems $372.6-438.3$ units $/ \mathrm{m}^{2}$ or $7.3-71.0$ units $/ \mathrm{m} 2$ compared to the control, in areas with strongly washed soils, these values are $501.8-553.7$ or $8.6-60.5$ units/ $\mathrm{m}^{2}$, respectively, and 357.8-418.9, or 6.2-67.3 units/ $\mathrm{m}^{2}$ higher than the control.

The soil of the experimental field grown in the unwashed control variant was $8.2 \mathrm{~cm}$ long, the number of grains per grain was 13.4, the number of grains of per grain was 34.5, and the mass of 1000 grains of per grain was 1.29 and 34.8 grams, respectively, these figures were taken into account that in the strongly washed part of the soil of this area, it is $7.9 \mathrm{~cm}, 12.1$ units, 32.7 units 1.27 and 32.6 grams, respectively. Indicators of structural elements of autumn wheat yield under the influence of norms of repeated crops and mineral fertilizers $\left(N_{150} P_{105} K_{75}\right.$ and $N_{180} P_{126} K_{90}$ $\mathrm{kg} / \mathrm{ha}$ ) - length of grain is $1.5-0.9 \mathrm{~cm}$ if the number increased from 1.4 to 1.1 units, the number of grains in one grain increased from 0.8 to 0.5 units, and the mass of 1000 grains in one grain increased to 1.23-1.15 and 3.5-2.9 grams, respectively, it was noted that these figures were slightly higher in the alfalfa variant.

In our experiments on typical gray soils subject to irrigation erosion, it was observed that the stratified application of repeated crop and mineral fertilizer rates had a significant positive effect on the yield and quality of autumn soft wheat grains. For example, in the unwashed soil control (non-replanting) variant of the soil of the experimental field, the autumn wheat grain yield was $15.7-16.5 \mathrm{c} / \mathrm{ha}$, and in the heavily washed part of the experimental field, the grain protein content was $14.2-15.4 \mathrm{c} / \mathrm{ha}$ in amount, $11.8-12.4 \%$, gluten $27.8-28.2 \%$ and 10.6-11.4, 26.7-27.5\% respectively;. Under these conditions, the average yield of autumn wheat in the unwashed soil variants planted after repeated crops (beans, mung bean, soybeans, peas, alfalfa) and mineral fertilizers $\left(N_{150} P_{105} K_{75} \mathrm{~kg} / \mathrm{ha}\right)$ was moderate $(68.8-70.4 \mathrm{c} / \mathrm{ha})$, grain protein content 14.8-15.6 and gluten 31.8-32.4\%, grown after the above repeated crops and applied in the amount of fertilizers $\left(N_{180} P_{126} K_{90} \mathrm{~kg} / \mathrm{ha}\right)$, autumn wheat in areas with strongly washed soils grain yield $(69.2-71.5 \mathrm{c} / \mathrm{ha})$ and the protein content of the grain was $15.2-15.8 \%$ and gluten $32.1-32.8 \%$.

\section{CONCLUSIONS}

Optimal secondary crop of beans, lentils, soybeans and perennials, which reduces the negative effects of erosion processes, increases soil fertility, improves its water-physical, agrochemical properties, provides high and high-quality grain harvest from winter wheat in the conditions of typical gray soils of Samarkand region optimal standards for the application of stratification of alfalfa and mineral fertilizers, taking into account the degree of soil washing, were selected. 
It has been identified that after repeated crops (beans, lentils, soybeans, peas, alfalfa) grown in typical gray soils subject to irrigation erosion, the volume mass of the top seedbed $(0-30 \mathrm{~cm})$ in areas where the soil was not washed before sowing autumn wheat seeds $0.03-0.05 \mathrm{~g} / \mathrm{cm}^{3}$ less, porosity $1.9-2.5 \%$ higher respectively, and in the heavily washed part of the soil it is $0.02-0.04$ $\mathrm{g} / \mathrm{cm}^{3}$ less and $1.7-2.3 \%$ more soil water permeability $-38.3-51.2 \mathrm{~m}^{3} / \mathrm{ha}$ compared to the control (non-replanted) and 24.9-42.7 m3/ha at the end of the application period, providing more water absorption, complete winter wheat seeds (92.3-91.5 \%) created the most favorable conditions for germination, growth and development.

Under the influence of repeated crops and mineral fertilizers $\left(N_{150} P_{105} K_{75} \mathrm{~kg} / \mathrm{ha}\right)$, when the soil of the experimental field was not washed and strongly washed control (not replanted), the yield of autumn wheat was 16.5 and $15.4 \mathrm{c} / \mathrm{ha}$, respectively, grain yield in unwashed soil variants (68.8-70.4 c/ha), grain protein 14.8-15.6 and gluten 31.8-32.4\%, mineral fertilizers after repeated crops in areas with washed soil $\left(N_{180} P_{126} K_{90} \mathrm{~kg} / \mathrm{ha}\right)$ in the used variants, the yield (60.2-71.5 $\mathrm{c} / \mathrm{ha}$ ) and the protein content of the grain was 15.2-15.9 and the gluten was 32.1-32.8\%, during the current caronavirus pandemic period there is an important role in ensuring food security of the population.

\section{REFERENCES}

M.M.Kurbonov, R.Madrimov Agrochemical and physical-agrochemical properties of light gray soils under the influence of main, repeated and intermediate crops. "Soil, climate, fertilizer" Republican scientific and practical conference. Tashkent, UzNU, (2018). pp. 524-528.

S.Arabov, B.Suleymanov, R.Kuziev The main directions of efficient use of land resources, maintenance and restoration of soil fertility// Republican scientific and practical conference Tashkent: NU Uz. (2016). p3.11-18.

Z.K.Muminova, K.M.Muminov. Factors in increasing the fertility and autumn wheat yields of eroded gray soils. Monography. Samarkand, (2017). p. 220.

Sh.N. Nurmatov, G.N.Abdalova, A.Kh.Rakhimov, R.U.Rakhmonov. Factors of protection soil from irrigation erosion and increasing its fertility. Monography. Tashkent, (2018). p. 262.

R.Oripov, A.Buriev. Influence of co-past crops on soil fertility and autumn wheat yield. Uzbekistan Agriculture (Uzbekiston Qishloq Hujaligi)). Tashkent, (2016). № 2, p. 35.

R.Sh.Tillaev. The system of farming in our country. Agroilm, Tashkent, (2016). No1 (39). pp. 5254.

B.M.Kholikov, A.A.Iminov. Importance of repeated and intermediate crops in increasing soil fertility. Tashkent, UzPITI. (2011). pp. 161-162.

I.N.Khoshimov, M.Y.Djuraev. Growth and development of repeated crops on lands subject to irrigation erosion. Sb.Art. XII International Scientific Conference, Penza (Russia), (2018). pp.146-149.

B.M.Kholikov, F.B.Namozov. Efficient repeated crops. Uzbekistan Agriculture (Uzbekiston Qishloq Hujaligi). Tashkent, (2009). No4, p. 24.

Methods of agrochemical, agrophysical and microbiological research in irrigated cotton areas. Tashkent, UzNIIX, (1963). p. 440.

Methods of conducting field experiments. Tashkent, Uz NIIX, (2007). p. 145.

B.A.Dospekhov Methods of field experience. Moscow, Agropromizdat, (1985). p. 350. 